\title{
Simulation of components of mould board plough bottom using computer software
}

YAGNIK C. YOGANANDI, RAJVIR YADAV AND GAUTAMRAY M. VEGAD

Received : 20.01.2016; Revised : 18.02.2016; Accepted : 11.03.2016

See end of the Paper for authors' affiliation

Correspondence to :

YAGNIK C. YOGANANDI

Department of Farm

Machinery and Power, College

of Agricultural Engineering and

Technology, Anand

Agricultural University, GODHRA (GUJARAT) INDIA
-ABSTRACT : The goal of the modern farming systems is to economize energy consumption and to reduce farming costs. In this study tractor drawn mouldboard plough of two bottoms was considered. Three main forces like draft force, side draft and vertical component were considered in plough bottom design software. Mouldboard plough is primary tillage implement, so that plough bottom has high magnitude reaction forces from the soil during tillage and these reaction forces effects on construction elements of plough bottom directly. If the construction elements cannot compensate reaction forces, they become useless due to plastic deformation or fracture. Therefore, structure must have been designed as stable durable enough to avoid undesirable failure cases. Proper selection and use of agricultural machines are important factors to achieve this end. Selection of appropriate tractor power and implement is more complex and tedious due to computational work involved in solving the equations for draft and working width and depth of ploughing of mouldboard plough bottom. Thus, a computer programme will be developed in visual basic language to compute width and the dimensions of the plough bottom by entering the essential inputs like tractor available power, soil type etc. for a particular farm situation. Results obtained by using this software were validated by comparing the simulated dimensions with some of the commercially available mouldboard plough. Hence, the developed software can be used as a tool for designing mouldboard plough bottom for different horsepower of tractor and soil conditions.

- KEY WORDS : Simulation, Mouldboard, Force, Plough, Bottom

- HOW TO CITE THIS PAPER : Yoganandi, Yagnik C., Yadav, Rajvir and Vegad, Gautamray M. (2016). Simulation of components of mould board plough bottom using computer software. Internat. J. Agric. Engg., 9(1): 39-46. 